\title{
Validation of an instrument for systematizing nursing care in pediatrics
}

\author{
Validação de instrumento para sistematização da assistência de enfermagem em pediatria \\ Validación del instrumento para sistematizar la atención de enfermería en pediatría
}

Thalys Maynnard Costa Ferreira' ORCID: 0000-0001-8758-6937

Josefa Danielma Lopes Ferreira' ORCID: 0000-0003-4209-4781

Carla Lidiane Jácome dos Santos ORCID: 0000-0002-5101-4408

Kenya de Lima Silva' ORCID: 0000-0002-7955-2531

Jacira dos Santos Oliveira' ORCID: 0000-0002-3863-3917

Glenda Agra" ORCID: 0000-0002-7628-9029

Marta Miriam Lopes Costa ORCID: 0000-0002-2119-3935

'Universidade Federal da Paraíba. João Pessoa, Paraíba, Brazil. "Universidade Federal de Campina Grande. Campina Grande, Paraíba, Brazil.

How to cite this article: Ferreira TMC, Ferreira JDL, Santos CLJ, Silva KL, Oliveira JS, Agra G, et al. Validation of an instrument for systematizing nursing care in pediatrics. Rev Bras Enferm. 2021;74(Suppl 4):e20200222. https://doi.org/10.1590/0034-7167-2020-0222

\section{Corresponding author:}

Thalys Maynnard Costa Ferreira

E-mail: thalys_maynnard@hotmail.com

EDITOR IN CHIEF: Antonio José de Almeida Filho ASSOCIATE EDITOR: Marcos Brandão

\section{ABSTRACT}

Objective: to verify the validity of indicators' content referring to the instrument for data collection in children aged 0 to 5 years hospitalized in a pediatric clinic. Method: a crosssectional methodological study was carried out with 11 experts between January and May 2018. For data collection, the steps for validating the instrument's content were respected. For data analysis, Content Validity Index and Kappa agreement analysis were used. Results: after content analysis, a Content Validity Index of 0.94 and Kappa 0.71 was issued according to the experts' suggestions $81.9 \%$. Therefore, the instrument was suitable for applicability. Conclusion: the instrument proved to be valid in terms of content for pediatric care, contributing significantly to improving care for hospitalized children aged 0 to 5 years.

Descriptors: Nursing; Pediatrics; Validation Studies; Nursing Process; Nursing Care.

\section{RESUMO}

Objetivo: verificar a validade do conteúdo dos indicadores referentes ao instrumento para coleta de dados em crianças de 0 a 5 anos hospitalizadas em clínica pediátrica. Método: estudo metodológico, transversal, realizado com 11 especialistas entre os meses de janeiro e maio de 2018. Para coleta de dados, respeitaram-se as etapas de validação do conteúdo do instrumento. Para análise dos dados, utilizou-se o cálculo do Índice de Validade de Conteúdo e de análise de concordância Kappa. Resultados: após análise do conteúdo, emitiu-se um Índice de Validade de Conteúdo de 0,94 e Kappa de 0,71 segundo sugestões dos especialistas, $81,9 \%$. Logo, o instrumento esteve apto à aplicabilidade. Conclusão: o instrumento mostrouse válido quanto ao conteúdo para o cuidar em pediatria, contribuindo significativamente para a melhoria da assistência a crianças de 0 a 5 anos hospitalizadas.

Descritores: Enfermagem; Pediatria; Estudos de Validação; Processo de Enfermagem; Cuidados de Enfermagem.

\section{RESUMEN}

Objetivo: verificar la validez del contenido de los indicadores referentes al instrumento de recolección de datos en niños de 0 a 5 años hospitalizados en una clínica pediátrica. Método: estudio metodológico transversal, realizado con 11 especialistas entre los meses de enero y mayo de 2018. Para la recolección de datos se respetaron los pasos para la validación del contenido del instrumento. Para el análisis de los datos se utilizó el Índice de Validez de Contenido y el análisis de concordancia Kappa. Resultados: luego del análisis de contenido, se emitió un Índice de Validez de Contenido de 0,94 y Kappa de 0,71 de acuerdo con las sugerencias de los expertos, $81,9 \%$. Por lo tanto, el instrumento era adecuado para su aplicabilidad. Conclusión: el instrumento demostró ser válido en términos de contenido para la atención pediátrica, contribuyendo significativamente a mejorar la atención de los niños hospitalizados de 0 a 5 años.

Descriptores: Enfermería; Pediatría; Estudios de Validación; Proceso de Enfermería; Atención de Enfermería. 


\section{INTRODUCTION}

Today, the political scenario involving the guidelines and strategies that permeate health has raised the need for a confluence of actions aimed at the organization of nursing care. This, in turn, needs to be guided by scientific knowledge and supported by theories that support care practice, in addition to including actions and comprehensive care $\mathrm{c}^{(1-2)}$.

Considering the advancement in the profession and the technical-scientific support that nurses seek to achieve, the Federal Nursing Council (COFEN - Conselho Federal de Enfermagem) established the Systematization of Nursing Care (SNC) as a duty. COFEN made SNC viable from the application of Nursing Process (NP) as a instrument that allows nurses to implement their scientific knowledge to directly assist patients, family and others involved in health-disease process, thus characterizing the body of knowledge of nursing and promoting a more resolutive, effective care, directed to care practice ${ }^{(3)}$.

NP is composed of five interconnected stages, which direct and provide nurses with a system that supports the actions, favoring the effective and coherent registration of each one. It is from the NP that nurses reach the human being, from the care professionally provided in all their spheres of care as a being who is assisted in a biopsychosocial and spiritual way ${ }^{(4)}$.

With regard to pediatrics, rethinking pediatric care practices is of fundamental importance considering the specific demand inherent to each child, since it exceeds care work focused on technical curativism, thus expanding views and attitudes towards humanized care ${ }^{(5-6)}$.

Therefore, the applicability of instruments in nurses' practice aims to contribute to producing results favorable to cared beings' health conditions, measuring resolutive actions that are transformative when practiced under the conduction of critical and reflective thinking of professionals, as well as improving the record's quality, giving visibility to the path taken by patients from admission to discharge. Instrumentalizing nursing actions based on theories that meet clients' needs, in addition to managing activities to the point of making nurses' clinical care practice effective within the aspects that make up SNC, has become something vehemently sought in the branch of research focused technology of valid means that lead to the production and quality of nursing work ${ }^{(7-8)}$.

In child care, growth and development, the different propaedeutics managed according to the changes in children's basic human needs (BHNs), the investigation of signs and symptoms that demand a more accurate look that goes beyond the physical, and understanding children's pathophysiological differences early in life make pediatric care complex and unique. Therefore, using instruments that provide the opportunity for nurses' work as well as subsidize it from the NP process instrumentalization based on a nursing theory is paramount in the current care context ${ }^{(9)}$.

The content validation consists of an analysis of all items that evidence a content and that structure an instrument, being a method that allows the establishment of a sequence of topics to be carefully checked by judges selected under inclusion criteria, meticulously listed. Validating the content works, effectively, the mandatory requirements that an instrument presents to measure a phenomenon ${ }^{(10-11)}$.
Therefore, a detailed look was directed at the care developed for hospitalized children with the use of NP as a work instrument. We sought to contribute to the content validation of the nursing data collection instrument, given its implementation, used by nurses to care for hospitalized children aged 0 to 5 years living with chronic illness assisted in a pediatric clinic.

\section{OBJECTIVE}

To verify the validity of indicators' content referring to the instrument for data collection in children aged 0 to 5 years hospitalized in a pediatric clinic, based on Wanda Horta's Theory of Basic Human Needs.

\section{METHODS}

\section{Ethical aspects}

The study considered all the ethical precepts of Resolution 466/2012 and COFEN Resolution 564/2017, being approved by the Research Ethics Committee (REC) of Hospital Universitário Lauro Wanderley (HULW), Brazil.

\section{Design, place of study, and period}

A methodological, cross-sectional study, guided by STROBE, was developed in a pediatric clinic unit of a university hospital in the city of João Pessoa, Paraíba, from January to May 2018, consolidated in three phases: selection of experts for the study; execution of the Delphi technique and process of content analysis of variables by judges; data analysis and establishing the instrument's content validity ${ }^{(12-13)}$.

\section{Population or sample; inclusion and exclusion criteria}

The sample was composed of experts in the study field, totaling 15 judges to contribute to the validation path, initially. Of these, 11 accepted to be included in the process, as well as reached satisfactory values according to the inclusion criteria, described below in the first phase of research development, adapted as established by Ferhing ${ }^{(14)}$. They were selected, electronically, through their professional curricula and through snowball sampling ${ }^{(15)}$.

\section{Study protocol}

$1^{\text {st }}$ phase: through online access on Curriculum Lattes Platform, the judges' curriculum was sought after indication of the first judge who was part of the group. Soon, the group continued to be formed by means of snowball sampling ${ }^{(15)}$. The invitation to participate in the research was made through contact by e-mail, in which the objective and other information of the methodological design relevant to the study were explained. Subsequently, through the e-mail provided in the list of judges' curriculums, the Informed Consent Form (ICF) was sent in readiness to sign a consent inherent to their participation in the study as a judge.

In turn, 15 experts were listed; of these, 11 proposed to participate in the methodological path, and were analyzed under 
the criteria adapted to the present study: being a doctor in pediatrics or in nursing with an emphasis on pediatrics (score 4); being a master in nursing with an emphasis on pediatrics (score 3); having publications in indexed journals on the field of interest (score 2); exercising teaching in pediatrics for at least 3 years (score 2); being an assistant nurse working in clinical pediatrics for at least 3 years (score 2); being available for matching information electronically after clinical judgment (score 2). It was considered that the higher the sum of the scores, the greater the strength of the assessment evidence ${ }^{(16)}$. A satisfactory number of six to twenty judges is admitted for studies on validation of instruments and/or technologies, making the use of at least three experts substantially important ${ }^{(17)}$.

$2^{\text {nd }}$ phase: assessment of 11 doctors, in which it was sought through 3 rounds between sending by experts and feedback by the researcher, related to judges' corrections and suggestions about the instrument's content. It should be noted that the 11 experts were part of 3 Delphi rounds according to the need to reach a consensus inherent to each variable ${ }^{(18)}$.

All judges should indicate, for each item that composes the variable represented by an $\mathrm{BHN}$, through the answer guided by the respective analysis points of agreement Adequate, Inappropriate and Partially Adequate, how much they agreed about the relevance of content and sequence of items established in the variable analyzed. The judges, in turn, after the trial, met the clinical criteria inherent to the characteristics analyzed in the instrument domains, as well as unified the judgment relevant to the scores regarding children's clinical severity according to the variables represented by the instrument's BHNs, using nomenclature: 0 - No clinical risk; 1 - Low clinical risk; 2 - Moderate clinical risk; 3 - High clinical risk.

Shortly after acceptance, the instrument to be assessed, consisting of variables represented by BHNs, was sent with sufficient space for experts to issue suggestions and perform clinical judgment of pediatric examination characteristics. At the end of this form, there was space for recording experts' suggestions, recommendations, and comments, it is worth mentioning that they were optionally made during the instrument course due to assessment conditions of clinical risk characteristics and the content inherent to each topic. At the end, experts were certified proving their participation in the process of analyzing the instrument's content.

$3^{\text {rd }}$ phase: after reaching a consensus, quantified between $80 \%$ and $95 \%$ of the information analyzed by experts who contemplated the pertinence of the variable's content, appropriate sequence, as well as stratification and quantification of clinical variables with the interposed clinical risk, which culminated in the instrument's final structuring, the final form with the clinical risk values for each item was made available to experts. It should be noted that a level of agreement of at least $75 \%$ of judges was adopted as the decision criterion for obtaining maintenance, reformulation, inclusion or exclusion of an item, expression and/ or issue and establishment of clinical risk, showing after analysis a consensus in higher percentiles ${ }^{(19)}$.

The instrument consists of three sections. The first has patient identification data and hospital admission; the second has information on the history of previous hospital admissions and the current main complaint; the third is made up of BHNs that support the topics relevant to pediatric physical examination. It is aimed at the pediatric public from 0 to 5 years old due to the demands inherent to the criteria of development and growth, vitality patterns and physical aspects of clinical examination for children, differentiated in the respective age group in relation to the other stages of childhood (school) and adolescence. After analyzing the content, it was decided to structure the referred instrument in checklist format, composed of topics that integrate items related to the respective $\mathrm{BHN}$ applied to pediatrics, aiming at measuring the clinical character and establishing sections for professional nurses' impressions regarding clinical judgment within the exam.

\section{Analysis of results, and statistics}

For analysis, the data were organized in a Microsoft Excel spreadsheet through double typing and subsequent verification, in order to control possible errors and exported to the Statistical Package for the Social Sciences (SPSS) software, version 20.0. For presentation and analysis of results, descriptive statistics were used to calculate frequency in absolute numbers and percentages. To verify experts' agreement regarding item relevance, the calculation was performed using Content Validity Index $(\mathrm{CVI})$, achieved by dividing the number of judges who judged the item as adequate by the total number of experts. It was also analyzed the reliability of the agreement of item assessment in judges' assessment using the Kappa index (K), indicated as a complement to $\mathrm{CVI}^{(18)}$. For the global assessment, a calculation was performed by means of the ratio between the number of items considered adequate by the experts and the total number of items. As an acceptance criterion, an agreement of $\geq 0.75$ for CVI and $\geq 0.61$ for the Kappa index was established, taking into account the classification called substantial, for the referred index value, both for the assessment of each item and for the instrument's overall assessment ${ }^{(20)}$.

\section{RESULTS}

The panel of judges consisted of 11 nurses, seven (63.6\%) of whom had a doctorate in nursing with an emphasis on pediatrics and four (36.4\%) of doctors in pediatrics. Of these, 11 (100\%) are masters in nursing with an emphasis on pediatrics, eight $(72.7 \%)$ are women and the entire sample has more than three years of experience in hospital care in clinical pediatrics and also in teaching, with emphasis on child and adolescent health (100\%).

After instruments' completion and verification by experts, data were collected and analyzed quantitatively. Suggestions and judgments regarding the agreement between judges regarding the content and sequence of variables represented by BHNs and items of each one of them, as well as consensus regarding the values of stratification of the clinical risk of children submitted to assessment by the instrument, followed by their respective CVI and Kappa calculation values, item by item, data shown in Table 1.

It is evident that instrument components that had suggestions to be made due to disagreement among judges regarding variable 
content. The sequence of items was: need for nutrition; motility; physical and cutaneous-mucous integrity; neurological; growth regulation; vascular regulation; security, love and acceptance, gregarious; communication. With regard to obtaining consensual values of stratification of clinical risk, the most complex ones were oxygenation, elimination, neurological regulation, regulation of cell growth, security, love and acceptance, gregarious; communication.

According to judges' opinions regarding the representativeness of need for sleep and rest, thermal regulation, immune regulation, perception and communication, all criteria presented an adequate level of agreement, attesting item adequacy in the respective topics that make up the instrument as to pertinence content, clinical risk, and sequence $(C V I=1 / K=1)$. Moreover, the need for hormonal regulation was excluded from the instrument body due to the low CVI established after expert analysis, making the instrument a carrier of 16 variables. Suggestions, recommendations, changes and indications of substitution, inclusion or exclusion of items and stratification of clinical risk, issued by the judges, were analyzed and subsidized by support in pediatric literature and Wand Horta's BHN theory.

With the verification of all items analyzed in overview, the judges made explicit, in a great part, agreement with the content already existing in each variable of the instrument. Regarding the modifications made, the disagreements that led to suggested suggestions in a common result came from a consensus among experts represented by percentiles considered prevalent $81.8 \%$ $(n=9)$, with $C V I=0.81$. Therefore, in this study, changes were made considering consensual judgments among the group, a fact permitted by a careful execution of the Delphi technique, converging into a pertinent content after adjustments suggested by the experts, explained by CVI and Kappa agreement. The content validation procedure consolidated the instrument's final version with 16 variables characterized by Horta's BHN, with its 267 characteristics distributed among each one according to the health demands of hospitalized children aged 0 to 5 years.

\section{DISCUSSION}

In the need for oxygenation $(\mathrm{CVI}=0.81 / \mathrm{K}=0.75)$, a decisive domain in nursing care in pediatrics, the concept of central cyanosis was changed to central labial cyanosis; it was based on the principle of presenting bluish center-lip color as a severe form of lowered saturation levels in children, more easily detected around the lips and in the mouth mucosa itself, a fact also evidenced in an integrative study ${ }^{(21)}$. Regarding the values of stratification of clinical risk $(\mathrm{CVI}=0.81 / \mathrm{K}=0.75)$, consensual analysis occurred in the third round of Delphi, showing the complexity of the clinical analysis of potential respiratory problems in children, especially within the evaluative parameters physical examination; these aspects are inherent to the composition of the variable directly related to the clinical assessment of children's oxygenation ${ }^{(21-22)}$.

In need of nutrition $(\mathrm{CVI}=0.81 / \mathrm{K}=0.70)$, there was a consensus for the inclusion of enteral and gastrostomy routes of administration, thus adding more objective options with regard to the detection of children's feeding pathways. Moreover, stratification of clinical risk and item order reached satisfactory consensus and satisfactory agreement $(\mathrm{CVI}=0.90 / \mathrm{K}=0.91)$, based on the amount of conceptual judges' emissions related to children's nutrition over the instrument. This fact is explained by the condition of hospitalized children, in which the panorama of pediatric illness, especially in the context of chronic diseases, encompasses more complex care within basic needs; in this case, alternative feeding, a reality faced by nurses who care for children with gastric diseases, conditions that lead to the depreciation of nutrients, gastrointestinal malformations and neurological comorbidities that, in their majority, culminate in natural alimentary canal diversion through the gastrointestinal tract ${ }^{(23)}$.

In the need for hydration, the hypohydrate option was inserted, taking into account the stages of development of children dehydration. Dehydration consists of a pathology that leads children to considerable losses of electrolytes, liquids and, in more serious situations, nutrients, leaving him prone to systemic problems.

Table 1 - Distribution of the level of agreement among judges $(n=11)$ about the items related to the Basic Human Needs that make up the research instrument, João Pessoa, Paraíba, Brazil

\begin{tabular}{|c|c|c|c|c|c|c|}
\hline $\begin{array}{l}\text { Analysis criteria } \\
\text { Basic Human Needs }\end{array}$ & $\begin{array}{c}\text { Variable } \\
\text { content } \\
\%\end{array}$ & CVI/K* & $\begin{array}{c}\text { Stratification of } \\
\text { clinical risk } \\
\%\end{array}$ & $\mathrm{CVI} / \mathrm{K}$ & $\begin{array}{c}\text { Sequence } \\
\%\end{array}$ & CVI/K \\
\hline Oxygenation & 81.8 & $0.81 / 0.75$ & 81.8 & $0.81 / 0.75$ & 90.9 & $0.90 / 0.80$ \\
\hline Nutrition & 81.8 & $0.81 / 0.70$ & 90.9 & $0.90 / 0.91$ & 90.9 & $0.90 / 0.91$ \\
\hline Hydration and water /electrolytic regulation & 81.8 & $0.81 / 0.70$ & 90.9 & $0.90 / 0.91$ & 81.8 & $0.81 / 0.70$ \\
\hline Elimination & 90.9 & $0.90 / 0.85$ & 81.8 & $0.81 / 0.72$ & 90.9 & $0.90 / 0.85$ \\
\hline Sleep and rest & 100 & $1 / 1$ & 100 & $1 / 1$ & 100 & $1 / 1$ \\
\hline Motility & 81.8 & $0.81 / 0.74$ & 90.9 & $0.90 / 0.63$ & 90.9 & $0.90 / 0.63$ \\
\hline Body care & 81.8 & $0.81 / 0.77$ & 100 & $1 / 1$ & 90.9 & $0.90 / 0.83$ \\
\hline Physical and cutaneous-mucosal integrity & 81.8 & $0.81 / 0.77$ & 90.9 & $0.90 / 0.83$ & 81.8 & $0.81 / 0.77$ \\
\hline Thermal regulation & 100 & $1 / 1$ & 100 & $1 / 1$ & 100 & $1 / 1$ \\
\hline Hormonal regulation & 18.1 & $0.18 / 0.33$ & 18.1 & $0.18 / 0.33$ & 18.1 & $0.18 / 0.33$ \\
\hline Neurological regulation & 81.8 & $0.81 / 0.80$ & 81.8 & $0.81 / 0.80$ & 90.9 & $0.90 / 0.83$ \\
\hline Immune regulation & 100 & $1 / 1$ & 100 & $1 / 1$ & 100 & $1 / 1$ \\
\hline Cell growth regulation & 81.8 & $0.81 / 0.65$ & 81.8 & $0.81 / 0.65$ & 81.8 & $0.81 / 0.65$ \\
\hline Vascular regulation & 81.8 & $0.81 / 0.74$ & 90.9 & $0.90 / 0.91$ & 81.8 & $0.81 / 0.74$ \\
\hline Perception & 100 & $1 / 1$ & 100 & $1 / 1$ & 100 & $1 / 1$ \\
\hline Security/love and acceptance/gregarious & 81.8 & $0.81 / 0.63$ & 81.8 & $0.81 / 0.63$ & 81.8 & $0.81 / 0.63$ \\
\hline Communication & 100 & $1 / 1$ & 100 & $1 / 1$ & 100 & $1 / 1$ \\
\hline
\end{tabular}

Note: *Content Validity Index and Kappa Index. 
Hypohydration is an intermediate condition that can be detected in the nursing history, aiming at early interventions so that there is a previous reversal, not allowing the establishment of the condition of dehydration itself ${ }^{(21,23-24)}$. There are several signs of dehydration, such as the lowering of fontanelles, evidence of water loss characterized by decreased cerebrospinal fluid.

With regard to the clinical judgment report for the fontanelles, an item included for direct assessment of children's hydration status, the consensus was established with a view to opening the space for nurses' clinical description, considering that bulged, depressed, and normal definers, previously described in the instrument, were judged as limiting the clinical description of fontanelles. Such changes contributed to $\mathrm{CVI}$ and satisfactory agreement regarding the content and stratification of clinical risk. Furthermore, the sequence of items in the hydration variable was reestablished after analysis by the judges ( $C V \mathrm{l}=0.81 / \mathrm{K}=0.70)$, a fact evidenced after a consensual analysis of the percentiles described.

In the need for elimination in the vomiting assessment item, the field was inserted to describe the expelled secretion's characteristics, justified by the fact that the prediction of pathological aspects related to the disease condition and presentation through gastrointestinal eliminations. In pediatrics, vomiting are warning signs that lead nurses to act promptly, considering the vulnerability of pediatric patients in depressing the general and clinical condition from sequential gastric losses ${ }^{(23-24)}$. Pictures like dehydration and malnutrition, associated or not with hydroelectrolytic disorders, are easily installed in children under two years of age when they are in situations of unavoidable losses of gastric content, a fact evidenced by a study, demonstrating a significant relationship between age and aggravating factors of dehydration/malnutrition in children ${ }^{(24)}$.

The measurement and consensus of clinical risk scores was also complex $(\mathrm{CVl}=0.81 / \mathrm{K}=0.72)$, considering the specificities inherent to items assessing eliminations, permeating the three rounds of Delphi feedback with satisfactory return and content established at the end $(\mathrm{CVI}=0.90 / \mathrm{K}=0.85)$. The scores for the relevance of $\mathrm{CVI}$ and Kappa assumed excellent values, considering the importance of this variable in the clinical assessment of children and, under this perspective, considered as substantial.

In the need for motility, the option no movement was inserted, an item that did not exist previously to the instrument, and the establishment of change was signed between nine judges $(C V I=0.81 / K=0.74)$. Pediatric motility is vital, starting from the ideal of childhood and prediction of establishment of gait, proprioception, balance and neuronal development. However, the absence of movements is also a reality in pediatric clinics, a factor assessed during nursing anamnesis, with the objective of developing actions that seek to prevent the establishment of comorbidities and disorders related to the limitation of movements, such as skin lesions, food inappetence, deficit in children's body care and basic physiological functions ${ }^{(25)}$. Regarding the establishment of scores for stratification of clinical risk, a Kappa of 0.63 was assumed, considering the great variability of judgments inherent to assessment of children's neuromotor status, their intrinsic complexity to the pathological processes that affect the referred system and the difficult perception of nurses, leading to costly agreement among judges, however substantial.
In the need for body care $(\mathrm{CV}=0.81 / \mathrm{K}=0.77)$, it was considered necessary to insert the dichotomy between impaired and preserved for the item intimate hygiene and the space for the subjective judgment report regarding oral lesions, in view of nurses' need to describe the lesions present in the oral mucosa as a strategy for prevention, control and treatment of diseases related to the lack of aseptic care in children's oral cavity. With regard to intimate hygiene, considering the reality of pediatric care and the problem of lack of responsibility of the nursing team, sometimes of less complex care, intimate hygiene assessment of hospitalized children is configured as a primary factor for the clinical examination of nurses, not only for assessment criteria, but also daily intervention in case there is an imminent need detected in the discussion of the propaedeutics ${ }^{(26)}$. The consensus regarding the stratification of clinical risk in relation to body care was evidently reached among the group of experts in a satisfactory manner, reaching the maximum level of agreement, justified by the fact that this variable presents simple criteria aimed at basic care of nursing $(\mathrm{CVI}=1 / \mathrm{K}=1)$.

In the need for physical and cutaneous-mucosal integrity, the hemangioma option was inserted among the detectable skin changes, in addition to the hyperemic item to aid in the description of skin color $(\mathrm{CVI}=0.81 / \mathrm{K}=0.77)$. The option mucosal color was inserted for professionals' clinical description, opening space for nurses to discuss this characteristic. The order of items was maintained, only changing the sequence after inserting the item that highlights the hemangiomas $(\mathrm{CVI}=0.81 / \mathrm{K}=0.77)$. The physical assessment of children's skin is a point that requires an experienced clinical eye, considering the large number of conditions that affect hospitalized children's dermal tract. Symptomatic changes are the most frequent, such as local topical infections, such as cellulite, furunculosis, bullous impetigo caused by streptococcus and pyogenic post-bacterial invasion injuries, as well as unintentional traumatic injuries. This fact was also evidenced, with respect to cellulite and other post-streptococcal invasion infections, in a study developed in a pediatric hospital, corroborating the findings of this research ${ }^{(27)}$.

In the need for neurological regulation, the active and reactive option, as well as hypoactive, was inserted to classify the level of consciousness of newborns, considering the age range of 0 to 5 years that the instrument contemplates $(C V I=0.81 / K=0.80)$. In neonatology, the neuromotor awareness and response factor is determined and assessed through the reactions that the newborn expresses during physical examination, considering the absence of cognitive and perceptual discernment, making the classification of conscious and oriented to the neonatal public unfeasible, evidencing, in literature, judges' decision regarding the referred modification in the instrument ${ }^{(28)}$. In the seizure crisis item, it was decided to open a space for nurses' clinical description about the type of seizure and how many episodes of seizures the children presented.

Monitoring the age group that includes neonates, infants and preschoolers in their early childhood gives nurses the possibility of examining children who have a greater neuronal predisposition to seizure episodes. It is healthy to assess the condition when historically detected in pediatric anamnesis, especially with regard to the types of seizures and characteristics of crises during 
neuromotor, sensitive and even focal episodes. In the description of primitive reflexes, there was consensus due to the absence of handgrip, plantar, galant, search, escape from asphyxia, and blink reflexes; were inserted so that there is a better description of the neurological status of the children assessed, in addition to the insertion of compatibility options, described as totally for the age, partially for the age or not compatible, contemplating the neurological examination and the judgment of the current state of children assessed $(\mathrm{CVI}=0.81 / \mathrm{K}=0.80)$. Neuronal milestones are predictive for conduct in clinical pediatrics, considering the range of pathological aspects that can be found during the nursing investigation of children with neural disorders ${ }^{(28-30)}$.

Nurses who deal with neuromotor diseases need to include an accurate sensorimotor assessment in the exercise of care, taking into account each cognitive competence and primitive sign of development of cognition, gnosis, central and peripheral response of infants' nervous system. This fact makes knowing how to care in pediatrics complex, bringing to professionals the responsibility of detecting conditions and, substantially, knowing how to treat them. Therefore, judges' assessment regarding the insertion of primitive reflexes in the field of the instrument regarding neuronal assessment becomes pertinent and healthy ${ }^{(29-30)}$. The adequacy of values for clinical risk score in the field of the need for neurological regulation was consensual $(\mathrm{CVl}=0.81 / \mathrm{K}=0.80)$, based on the criterion of reaching the neural milestones as a low risk factor, considering the physiological and doable to children during their growth. However, when submitted to the absence of these, children are scored with significant scores, a fact considered by the experts together during the execution of the clinical risk predictive factor.

In the need to regulate cell growth $(\mathrm{CVl}=0.81 / \mathrm{K}=0.65)$, compatibility options were inserted, described as totally for age, partially for age or not compatible, considering the description in this item of child development and growth milestones to be identified by nurses during physical examination. The decisions related to the risk score values $(\mathrm{CVl}=0.81 / \mathrm{K}=0.65)$ and variable content were made from the perspective of Integrated Management of Childhood IIIness (IMCI), considering the integrality pertinent to the criteria listed in the strategy, a fact of great value to nurses, leading judges to modify the clinical judgment of the reach of the referred milestones according to age, adequacy of presentation sequence $(C V I=0,81 / K=0.65)$ and their score values, the latter being worked on the same strand of considerable values of primitive reflexes for when not compatible with age ${ }^{(31)}$.

In the need for vascular regulation, there was consensus among judges that there was a change in the writing field related to cardiological findings' clinical description. The instrument did not have an appropriate place, taking, by the group's judgment, in a third round of feedback from Delphi, the opening for nurses to discern and discuss their findings. Moreover, the subjective assessment criteria of types of cardiovascular diseases that children may have or have a history were defended, the description of venous access, if installed, and its location, in addition to a space for systemic assessment of the edematous sign of Godet, described in crosses.

Cardiological propaedeutics leads nurses to investigate the signs of cardio-circulatory worsening that children may have, whether due to a congenital or acquired disease. Understanding the picture of heart diseases requires precision in conduct and scientific knowledge to make them feasible, developing and guiding the care plan. The cardiological status classification as normocardial and its derivations for the abnormality, heart rhythm and its alterations of consonance that differ from the sinus, characteristics of heart sounds and their reverberative sonority, presence or absence of heart murmur, assessment of pulses, peripheral perfusion and circulatory situation are indispensable factors for the propaedeutics of nurses who take care of children, making judges' judgment consistent with the modification of the variable content and the logistic sequence of the technical presentation of the record coherent $(\mathrm{CVI}=0.81 / \mathrm{K}=0.74)^{(30)}$.

In the need for security, love, acceptance and gregariousness, as it is a domain of needs that exceed the biological understanding, covering aspects such as feelings and subjective reactions of children to stimuli and established social relationships, there was a degree of difficulty for agreement among experts. However, after the third round of feedback and feedback in Delphi, there was a consensus regarding the content relevant to the expression of childhood affection $(\mathrm{CVI}=0.81 / \mathrm{K}=0.63)$, represented by the expression of feeling by other people item, remaining unchanged, changing only the order of presentation $(\mathrm{CVI}=0.81 / \mathrm{K}=0.63)$. The judgment of values of stratification of clinical risk was inherent to conditions related to pathological conditions $(C V l=0.81 / K=0.63)$, such as depression, anxiety, apathy, irritability, and aggression, considering the absence of possibilities measurement of subjective items, such as holding on to the companion in the presence of other people, avoiding family members and fear.

The level of agreement related to the instrument in its totality of items, obtained among judges, was considered satisfactory; however, with the proviso that the need for hormonal regulation was removed from the instrument, considering the absence of clinical contribution to the assisted public according to experts suggestions, $81.9 \%(n=9)$. Two judges affirmed content contribution and adequacy to the pediatric public $18.1 \%(n=2)$, assuming a $C V I=18.1$ and $K=0.33$, leading the instrument to reach a CVI level of 0.94 and Kappa 0.71 in all items, with expressive relation of judges' substantial agreement. Considered high, this value makes it intrinsically suitable for clinical applicability in pediatric care practice.

\section{Study limitations}

Lack of return of contact via email regarding the selection process for being a judge became an express limitation, even though there was, in the end, a number of experts included in the judging panel considered satisfactory. This fact hinders the progress of this research during the structuring of the body of experts, an aspect that must be questioned among researchers and collaborators of methodological studies of a validating nature.

\section{Contributions to nursing and health}

The study made it possible to identify the instrument validity and, as a contribution, the safe use and explicit relevance to the use of a instrument for nursing care primacy, mediated by valid attributes regarding the particularities of each person under care nurses as managers. Furthermore, verifying the condition of NP implementation, based and guided by scientific knowledge, 
makes the study something absolutely salutary to the category of professionals who deal with care practices in their work.

The instrument's systematic use in pediatric care enables caring for this type of population, demonstrating the complexities of being a child between the lines of each action of nurses, making the need for commitment on the part of nursing research aimed at the public notorious pediatric and the instruments used. The results corroborate the importance of conducting methodological studies within nursing, as they transform technologies directly linked to the work of nurses into honorary attributes for the growth of health work, more precisely in the professional category of nursing.

\section{CONCLUSIONS}

The instrument proved to be valid in terms of its content, inherent to each variable and item that composes it. The growing need to create and improve valid instruments offered to health services becomes explicit, aiming to direct care that is proposed during its applicability.

Thus, it is emphasized the need for further studies that address improvements with regard to the instrument worked here, as well as the expansion of its applicability within the stage of data collection of NP in other fields of assistance to hospitalized children, leading to the detection of minute details pertinent to the improvement of the strategy of conducting thought and clinical information of children in their health-disease process.

The need for clinical validation of the instrument is made clear, considering the great contribution in terms of the instrument's validation path, corroborated with regard to the relevance of clinical data verified with hospitalized children. Valid and reliable instruments contribute to high quality health actions and interventions.

\section{REFERENCES}

1. Watson J. Clarifying the discipline of nursing as foundational to development of professional nursing. Texto Contexto Enfermagem. 2017;26(4):1-2. https://doi.org/10.1590/0104-07072017002017editorial4

2. Viana JC, Cunha NN, Leão RA. Role of the professional nurse and its importance in pediatric assistance. J Especialist [Internet]. 2019 [cited 2019 Dec 21];3(3)1-14. Available from: http://www.journalofspecialist.com/jos/index.php/jos/article/view/107/61

3. Conselho Federal de Enfermagem. Resolução COFEN n. 358/2009. Dispõe sobre a sistematização da assistência de enfermagem e a implementação do processo de enfermagem em ambientes públicos ou privados, em que ocorre o cuidado profissional de enfermagem e dá outras providências [Internet]. 2009 [cited 2019 Oct 12]. Available from: http://www.cofen.gov.br/resoluo-cofen-3582009_4384.html

4. Giehl CT, Costa AEK, Pissaia LF, Moreschi C. Team nursing front of the implementation process of nursing care systematization. Rev Enferm Atenção Saúde [Internet]. 2016 [cited 2018 Oct 18];5(2):87-95. Available from: http://seer.uftm.edu.br/revistaeletronica/index.php/enfer/article/view/1621

5. Miranda AR, Oliveira AR, Toia LM, Stucchi HKO. The evolution of nursing care models of in-hospital children in the last 30 years: from a disease centered model to a child and family centered model. Rev Fac Ciênc Méd [Internet]. 2015 [cited 2018 Oct 12];17(1):5-9. Available from: http://revistas.pucsp.br/index.php/RFCMS/article/viewFile/12890/pdf

6. Silva IC, Santos FC, Prudêncio FA. Role of nursing and family in the care and recovery of the hospitalized child. Rev Saúde Foco [Internet]. 2017 [cited 2018 Out 12];(4)1:58-66. Available from: http://www4.fsanet.com.br/revista/index.php/saudeemfoco/article/view/1506

7. Benedet AS, Gelbcke FL, Amante LN, Padilha MIS, Pires DP. Nursing process: systematization of the nursing care instrument in the perception of nurses. Rev Pesqui: Cuid Fundam. 2016;8(3):4780-8. https://doi.org/10.9789/2175-5361.2016.v8i3.4780-4788

8. Gomes RM, Teixeira LS, Santos MCQ, Sales ZN, Linhares EF, Santos KA. Sistematização da assistência de enfermagem: revisitando a literatura brasileira. Id on Line Rev Mult Psic [Internet]. 2018 [cited 2019 Feb 12];12(40):123-34. Available from: https://idonline.emnuvens.com.br/id/ article/view/1167

9. Prado NCC, Santos RSC, Lima DM, Góis MMCD, Costa RHS, Silva RAR. Changed basic human needs in neonates with peripherally inserted central cateter. Rev Enferm UERJ [Internet]. 2019 [cited 2020 Oct 08];1(27):1-8. Available from: https://www.e-publicacoes.uerj.br/index.php/ enfermagemuerj/article/view/44521

10. Ferreira TMC, Lima CLJ, Ferreira JDL, Azevedo LR, Silva KL, Costa MML. Validation of instruments for care in pediatrics: an integrative study. Enferm Global. 2019;16(6):625-9. https://doi.org/10.6018/eglobal.18.4.357381

11. Resende FZ, Almeida MV, Leite FM, Brandão MA, Cubas MR, Araújo JL, Primo CC. Terminological subset of the International Classification for Nursing practice (ICNP ${ }^{\oplus}$ ) for breastfeeding support: content validation study. Acta Paul Enferm. 2019;32(1)35-45. https://doi. org/10.1590/1982-0194201900006

12. Szabluk D, Berger AVF, Capra A, Oliveira MF. Experience design applied to research: an exploratory method of user centered research. Human Factors Design [Internet]. 2019 [cited 2019 Oct 12];15(8)98-113. Available from: http://www.periodicos.udesc.br/index.php/hfd/ article/view/2316796308152019098/9861

13. Von Elm E, Altman DG, Egger M, Pocock SJ, Gøtzsche PC, Vandenbroucke JP, STROBE Initiative. The Strengthening the Reporting of Observational Studies in Epidemiology (STROBE) statement: guidelines for reporting observational studies. J Clin Epidemiol. 2008;61(4):3449. https://doi.org/10.1016/j.jclinepi.2007.11.008

14. Melo RP, Moreira RP, Fontenele FC, Aguiar ASC, Joventino ES, Carvalho EC. Critérios de seleção de experts para estudos de validação de fenômenos de enfermagem. Rev Rene [Internet]. 2011 [cited 2019 Oct 30];12(2):424-31. Available from: http://periodicos.ufc.br/rene/article/view/4254/3285 
15. Vinuto J. A amostragem em bola de neve na pesquisa qualitativa: um debate em aberto. Temáticas. 2014;44(22):203-220. https://doi. org/10.20396/temáticas.v22i44.10977

16. Fehring R. Methods to validate nursing diagnosis. Heart Lung [Internet]. 1987 [cited 2018 Oct 12]; 16(6):625-9. Available from: https://pdfs. semanticscholar.org/11f7/d8b02e02681433695c9e1724bd66c4d98636.pdf

17. Schlindwein-Zanini R, Cruz RM. Psychometrics and Neuropsychology: inter-relations in the construction and adaptation of measuring instruments. Psicol Argum. 2018;36(91)49-69. https://doi.org/10.7213/psicolargum.36.91.AO04

18. Revorêdo LS, Maia RS, Torres GV, Maia EMC. The use of delphi's technique in health: an integrative review of Brazilian studies. Arqu Ciênc Saúde. 2015;22(2). https://doi.org/10.17696/2318-3691.22.2.2015.136

19. Pasquali L. Princípios de elaboração de escalas psicológicas. Rev Psiquiatr Clín [Internet]. 1998 [cited 2018 Aug 25];25(5):206-13. Available from: http://mpet.ifam.edu.br/wp-content/uploads/2017/12/Principios-de-elaboracao-de-escalas-psicologicas.pdf

20. Polit DF, Beck CT, Owen SV. Is the CVI an acceptable indicator of content validity? appraisal and recommendations. Res Nurs Health. 2007;30(4):459-67. https://doi.org/10.1002/nur.20199

21. Pereira JÁ, Escobar EMA. Nursing care to premature newborn with respiratory distress syndrome: an integrative review. Rev Saúde Foco. 2016;3(2):17-36. https://doi.org/10.12819/rsf.2016.3.2.2

22. Duarte PS, Maziero FF, Antoniassi DQ, Souza LT, Felix AF, Eloise D, et al. Acute respiratory diseases in Brazilian children: are caregivers able to detect early warning signs? Rev Paul Pediatr. 2018;36(1):3-9. https://doi.org/10.1590/1984-0462/;2018;36;1;00008

23. Oliveira ND, Silva EB, Moura RL, Dantas ENDA, Silva JCC, Cordeiro SA, et al. Efeitos da utilização da terapia nutricional enteral em crianças hospitalizadas: uma revisão. Int J Nutrology. 2018;11(S 01):S24-S327. https://doi.org/10.1055/s-0038-1674648

24. Brandt KG, Castro Antunes MM, Silva GA. Acute diarrhea: evidence-based management. J Pediatr (Rio J). 2015;91(6-supl 1.1):36-43. https:// doi.org/10.1016/j.jped.2015.06.002

25. Lopes TAMC, Monteiro MFV, Oliveira JD, Oliveira DR, Pinheiro AKB, Damasceno SS. Diagnósticos de enfermagem em crianças hospitalizadas. Rev Rene. 2017;18(6):756-62. https://doi.org/10.15253/2175-6783.2017000600008

26. Sarmanho CLB, Gonçalves KLP, Nogueira MA, Melo MF, Teixeira RC. Estratégia lúdica no ensino de boas práticas de higiene à crianças hospitalizadas. Int J Health Educ. 2016;1(2)143-50. https://doi.org/10.4322/ijhe.2016.023

27. Más M, Tórtora S, Morosini F, Hernández K, Benítez MA, Orso PD, et al. Infecções cutâneas e de partes moles com tratamento ambulatorial num hospital pediátrico do Uruguai depois de 10 anos da epidemia SAMR. Arch Pediatr Urug. 2018;89(4):251-56. https://doi.org/10.31134/ap.89.4.4.

28. Silva TP, Silva MM, Silva LJ, Silva IR, Leite JL. Contextual specificities of nursing care to hospitalized children with chronic condition. Cienc Cuid Saude. 2015;14(2):1082-90. https://doi.org/10.4025/cienccuidsaude.v14i2.23814

29. Freitas ZMP, Pereira CU, Oliveira DMP. Influência da avaliação neurológica seriada durante período de internamento hospitalar e seus reflexos no prognóstico funcional de recém-nascidos a termo com asfixia perinatal. Rev Bras Neuro Psiq [Internet]. 2018 [cited 2019 Jan 20];22(2):142-56. Available from: https://www.revneuropsiq.com.br/rbnp/article/view/409/158

30. Mota CC. Pediatric cardiology in the 21st century: advances and challenges. Nascer Crescer. 2019;28(4)174-8. https://doi.org/10.25753/ BirthGrowthMJ.v28.i4.19085

31. Martignago G, Corrêa MV, Campomor C. Educação permanente do público-alvo para detecção precoce de alterações neuromotoras infantis. Rev Eletron Extensão. 2018;15(31):79-93. https://doi.org/10.5007/1807-0221.2018v15n31p79 